\title{
The Heuristic Approach from the Perspective of Student-Centred Learning
}

Ioana-Maria Câmpean 


\title{
The Heuristic Approach from the Perspective of Student-Centred Learning
}

\author{
Ioana-Maria Câmpean ${ }^{\mathrm{a}^{*}}$ \\ ${ }^{a}$ Doctoral School „Education, Reflection, Development”, Faculty of Psychology and Educational Sciences, Babes Bolyai University \\ Cluj-Napoca, 7 Sindicatelor Street, Romania \\ *Corresponding author: ioanamariacampean@gmail.com
}

\section{Abstract}

Keywords:

Heuristic approach Discovery

Active learning

Student-centred learning

Problem-based learning

\section{Zusammenfasung}

Schlüsselworte:

Aktives Lernen Lentdeckendes Lernen Heuristischer Ansatz Problemlösen Schülerzentriertes Lernen
The rapid evolution of modern society compels changes in each person's objectives and fundamental needs. It is therefore critical to efficiently anticipate the professional behaviours and profiles best equipped to adjust easily to an ever-changing future. From this perspective, the formation of the future generation gains new dimensions, and education must shift its focus. Student-centred learning has become the goal of the current educational mindset, perfectly integrated in the European environment. In this model, the student becomes the leading actor in his/her own evolution, and is given the responsibility of his/her progress. The heuristic approach gains a well-deserved role in an instruction process specific to our times, and it identifies with methods such as problem-based learning and discovery. This approach offers new perspectives on the development of competences, which are understood as an operating mode which employs knowledge, skills and abilities, but also builds attitudes towards knowledge and life.

Die gegenwärtige Entwicklung der Gesellschaft führt zur Veränderung der Ziele und Bedürfnisse jedes Menschen. Durch den stetigen Wandel wird es immer wichtiger, das zukünftige professionelle Verhalten schon heute antizipieren zu können. Aus dieser Sicht bekommt die Bildung der kommenden Generationen neue Bedeutung und der Fokus des Bildungsprozesses ändert sich. Schülerzentriertes Lernen ist deshalb eines der großen Ziele des heutigen Bildungssystems und integriert sich perfekt in die europäische Realität. Dadurch wird der Schüler der Hauptakteur seiner Entwicklung und ist selbstverantwortlich für seinen Fortschritt. Der heuristische Ansatz, der sich mit Methoden wie dem Problemlösen und entdeckendem Lernen identifiziert, spielt heutzutage eine wohlverdiente Rolle im aktuellen didaktischen Prozess. Diese Perspektive gewinnt bezüglich des Erlernens von Kompetenzen neue Bedeutung. Dieser Prozess ermöglicht es dem Schüler, mit Hilfe der neu erworbenen Kenntnisse und Fähigkeiten sich eine Einstellung über das Wissen und Leben zu bilden.

\section{Introduction}

In contemporary society, student-centred learning provides the solution to a series of problems, while offering the warranty of quality and efficiency of the instruction process. The issues and difficulties thus addressed are: lack of student motivation; lack of group cohesion; minimal engagement in academic activities; excessive focus on memory and reasoning over emotional intelligence, imagination, creativity; priority given to mechanical approaches over heuristic approaches; passive approach of instruction by some teachers; daily routine of all participants to education; and even decline of academic performance. The changeover of the social environment and of everyday life's dynamics leads to new horizons of student expectations from school realities. Rarely do teachers' standards match students' expectations, and the former are often found in the situation to be unable to relate to their students, or to understand their aspirations, interests and concerns.

In these circumstances, student-centred teaching and learning comes as a redeeming solution, aimed to redesign the entire classroom activity and to breathe new life into Romanian education. "Student-centred learning is an active strategy, which requires the construction of a positive and meaningful learning experience in real time, within a democratic and non-directive relationship” (Șoitu, Cherciu, 2006). „Student-centred learning describes approaches to teaching and learning which place the focus on the student's responsibility for activities such as planning, learning, interacting with teachers and other students, research and assessment” (Cannon, Newble, 2000). „Student-centred learning provides students with greater autonomy and control over the selection of the subject of instruction, instruction methods and learning pace." (Gibbs, 1995).

\section{Student-centred learning - the goal of $21^{\text {st }}$ century's education}

Student-centred learning implies the shift of focus on active learning, on the integration of learning situations, which unfold at the pace specific to each student or work group, providing learners with the responsibility of their own progress. The teacher is no 
longer the provider, but the facilitator of knowledge and instruction, and the student becomes the leading actor in its own development and progress. Student-centred learning has emerged from the necessity to satisfy students' need of knowledge, to redesign the approach to teaching and learning, and to reconsider the teaching process. "When they are actively engaged in the teaching-learning process, students are no longer a simple audience ready to passively receive what is being taught or demonstrated" (Şoitu, Cherciu, 2006), but they become active part of instruction. However, to ensure a genuine activation of students in the classroom, it is important to remember that the involvement of the subject of learning is ,quantitatively and qualitatively dependent on its own subjectivity, on the subjective interpretation of the instructional tasks, on the relevance and significance of instructional content at the level of its subjectivity” (Bocoş, 2013).

Student-centered typically refers to forms of instruction that, for example, give students opportunities to lead learning activities, participate more actively in discussions, design their own learning projects, explore topics that interest them, and generally contribute to the design of their own course of study. Additionally, student-centered instruction is often associated with classrooms that feature desks arranged in circles or small groups (rather than rows of desks that face the teacher), with ,self-guided" or ,selfpaced" learning, or with learning experiences that occur outside of traditional classroom settings or school buildings, such as internships, apprenticeships, independent research projects, online classes, travel experiences, community-service projects.

Student-centered learning has defined circumstances where the individual determines the learning goal, learning means, or both the learning goals and means. Accordingly, the individual may establish specific individual and pursue learning goals with few or no external boundaries as typical during spontaneous, self-initiated informal learning. Alternatively, the individual may have access only to specific, defined resources to pursue individual learning goals, such as during free-time learning in formal settings. In cases where learning goals are externally established as in most formal school settings, the individual determines how they will be pursued. In essence, the cognitive demands shift from externally mediated selecting, processing, and encoding during directed learning to individually anticipating, seeking, and assessing relevance based on unique needs and goals.

A student-centred learning activity relies, first and foremost, on the personal characteristics of the student; its main objective is to build competences and its secondary objectives to transfer specific contents, to engage the student in the planning, instruction and assessment, creating positive learning experiences and enabling the transfer of knowledge onto a future learning experience.

An active lesson is built on active methods and techniques, and addresses the dynamism in each and every child. Active and participatory methods fulfil two functions: formative/cognitive, since students assimilate knowledge during the instructional process and formative/educational, since children gain intellectual, motivational and emotional skills and abilities, and develop their personality (Bocoş, 2013). The diversity of methods employed address their needs of dynamism, differentiation and particularization of the instructional activities. As such, the teaching experience becomes richer and the learning experience becomes more diversified and tailored to the needs of each student.

A pertinent classification ranks the methods specific to interactive teaching-learning as follows (Bocoș, 2013):

- methods for the development of an active mind (including personal reflection, drilling and problemsolving, experiment-based learning, learning by problembased learning, discovery and cooperation, model-based learning, problem-based learning, E- learning etc.),

- methods and techniques for the development of critical thinking (the cube method, the quintet method, reciprocal teaching, gallery tour etc.) and

- methods for the development of creative thinking (brainstorming, idea engineering, synectics, Frisco, creative visualisation etc.).

One of teachers' challenging duties is to select the range of strategies suitable for a given activity. This decision should consider context-related elements and curriculum-related elements. Only by activating the subject of learning can teachers build positive learning experiences, which are useful and relevant for the learner.

\section{Research methodology}

Heuristic ,is a guiding idea, a guiding principle in the entire instructional methodology", where the ,role of organising tool in the heuristic strategy belongs to the concepts which are the subject matter of the teaching-learning process, given that such concepts determine the selection of objectives and events to be discusses and observed throughout the class" (Ionescu, Radu, 1995).

„Heuristic is a guiding principle in the methodology of interactive teaching, which recommends that the learning content should not be delivered to students in a processed and final form, but in a state which requires reorganisation and retransformation, capable to provide a pretext for individual investigation and research (Bocoş, 2013).

\section{Research}

The question of this research is: Which are the valences of the heuristic approach involved in achieving quantified school results in national tests for the primary school sudents? Given that, we formulated the hypothesis of the research: Applying the heuristic approach to the study of Romanian Language and Literature, Mathematics and Science in the $3^{\text {rd }}$ and $4^{\text {th }}$ grades contributes significantly to the improvement of quantified school results in national tests. We identified the methods of the research:

- the psycho - pedagogical experiment method;

- the method of researching curricular and legislative documents;

- the test method and other written examinations; 
- the method of analyzing the outcome of the activities;

- the method of observation.

The experiment has taken place over three school years: 20142015, 2015-2016, 2016-2017. The experimental sample is formed by 90 students of ,Nicolae Bălcescu” Highschool from ClujNapoca, and the control sample sums 123 students from different educational institutions from the same locality, schools comparable in tradition, performance and prestige.

The decisive stage coincided with the administration of the National Tests. These exams represent the initial testing of the research and they are inserted in The Law of Education, being designed as objective, ascertaining evaluation programmes. Also, they assess the fundamental competences acquired by students, and they are given at the end of the $2^{\text {nd }}, 4^{\text {th }}, 6^{\text {th }}$ and $8^{\text {th }}$ grade in Romania. The National Tests have a similar format to international evaluation tests.

The formative stage has taken place throughout two school years, 2015-2016 and 2016-may, 2017, and it includes a variety of didactic activities, which determined the students to engage actively in carrying out the tasks. The planning of this stage's didactic actions had as a main pillar the heuristic approach, built according to integrated teaching and learning.

Group work was one of the active-participative methods we adopted countless times because it implies cooperation in resolving certain tasks. Psychopedagogical research, which also concerns the sociology of education highlighted a greater productivity of the students who work in groups. Without disregarding the individuality of the student, the method emphasises the advantages of school work and extracurricular activities in groups, ensuring conditions so that the common effort is well organised and well sustained. This method targets, in particular, the social aspect of learning, the development of the student's social behaviour. It is a way of combinig individual learning with social learning and, to the same extent, with a manner of mitigation of an exaggerated individuality.

Its use presumes the understanding of the way in which the groups can be composed. During the experiment we proposed, we opted for two different ways of putting together the work groups. Firstly, the students were split based on their learning style, the requests being formulated explicitly for each intelectual profile in part. Secondly, they were put in aleatory groups, in which the requests were common for each team, but the working manner and the children's approach angles were different. Due to the fact that each didactic activity of this kind finalises with the product presentation of the activity of each team, the whole class benefits, because it can experience different approaches of the same subject.

During the Romanian Language and Literature class, we integrated other knowledge from subjects such as Science, Mathematics, Geography, Visual Arts, History. In addition, we took into account the students' learning styles, so that the formulated tasks will target these particular aspects. A specific example is mentioned below:

- The actors' group carried out the following task: „Create a pantomime moment, presenting the main events from the narative text $<<$ The Elf of the Rose $>>$, by H. Ch. Andersen."

- The researchers' group had the following task: „Find as much information as you can about the plants which appear in the text $<<$ The Elf of the Rose $>>$."

- The handy-students' group received the following task: „Create, from leaves, the gazebo described in the story $<<$ The Elf of the Rose $>>$."

- The painters' group had to carry out the following task: „Draw the elves' portrets as they appear in the narative text $<<$ The Elf of the Rose $>>$."

- The generous-students' group had to accomplish the following task: „Help your collegues by doing team work!”

We consider that offering such tasks as the one of the ,generous-students" represents one of the skills which are necessary for the future adult. This capacity refers to developing and maintaining social interractions, and also to the interpretation of certain situations viewed from someone else's perspective. In one word, it refers to the development of empathy. The researchers' group, in order to accomplish their task (bringing additional information about the plants presented in the text), had access not only to the class' computer, but also to the botanical atlas from the class' library. The instruction assisted by computer allows the completion of a series of unique activities and developments such as modelings, stimulations and visualizations on the computer, but, especially, it allows making the experiment on the computer, which represents the third way of scientific discovery, after the practical-empirical one and the logicalmathematical one. Moreover, the improvement of the experiments with the help of the computer leads to overcoming the mathematical difficulties and to the profound understanding of certain laws which we would have not suspected without this new face of using the computer.

We used the pedagogical experiment for the science classes in particular, as it helped the students to make a connection between practice and theoretical knowledge. Each student will receive written-down instructions concerning the following experiment, along with some explicative drawings. These types of activities integrate subjects such as Romanian Language and Literature, Mathematics and Visual Arts, and they put the students in specific learning situations, from which they will learn about the surrounding world, in a fun and attractive way.

The post-experimental stage coincided with the administration of the National Tests from 2017, on the 3rd and the 4th of May (for the students who don't belong to the ethnic minorities). Also, during this stage, the reports and the individual files were filled out. They concerned the identification of the aquired competences for each student and, also, the skills which were in process of aquiring. The results obtained in 2017 were analysed and compared to the ones from 2015.

The stage of long-distance check has taken place one month after the National Test. This retesting's main purpose was to establish the durability of the acquisitions gained during the 
formative stage. In this phase, the demonstration of the formulated hypothesis is certified. The students had to elaborate the final exams of the cicle of education, but also the tests for the fourth grade. These were conceived in collaboration with the teachers from „Nicolae Bălcescu” Highschool, Cluj-Napoca, which were part of a comprehensive project organised by our institution: „I am moving on to middle school'".

\section{The results obtained and discussions/ the analysis of the results}

The results of the experimental investigation validate the fact that the didactic interactive strategies offer the premise of a thorough learning, accesible and pleasant, with a pronounced active-participative character from the students' part, with posibilities of efficient cooperation and communication. The experimental perspective of interactive learning-teaching strenghtens the belief that the heuristic approach constitutes an important strategy, which can be incorporated with success in the didactic strategy. The quantitative results, the interpretations and the observations of the experimental action proves the complex and subtle character of the learning-teaching process.
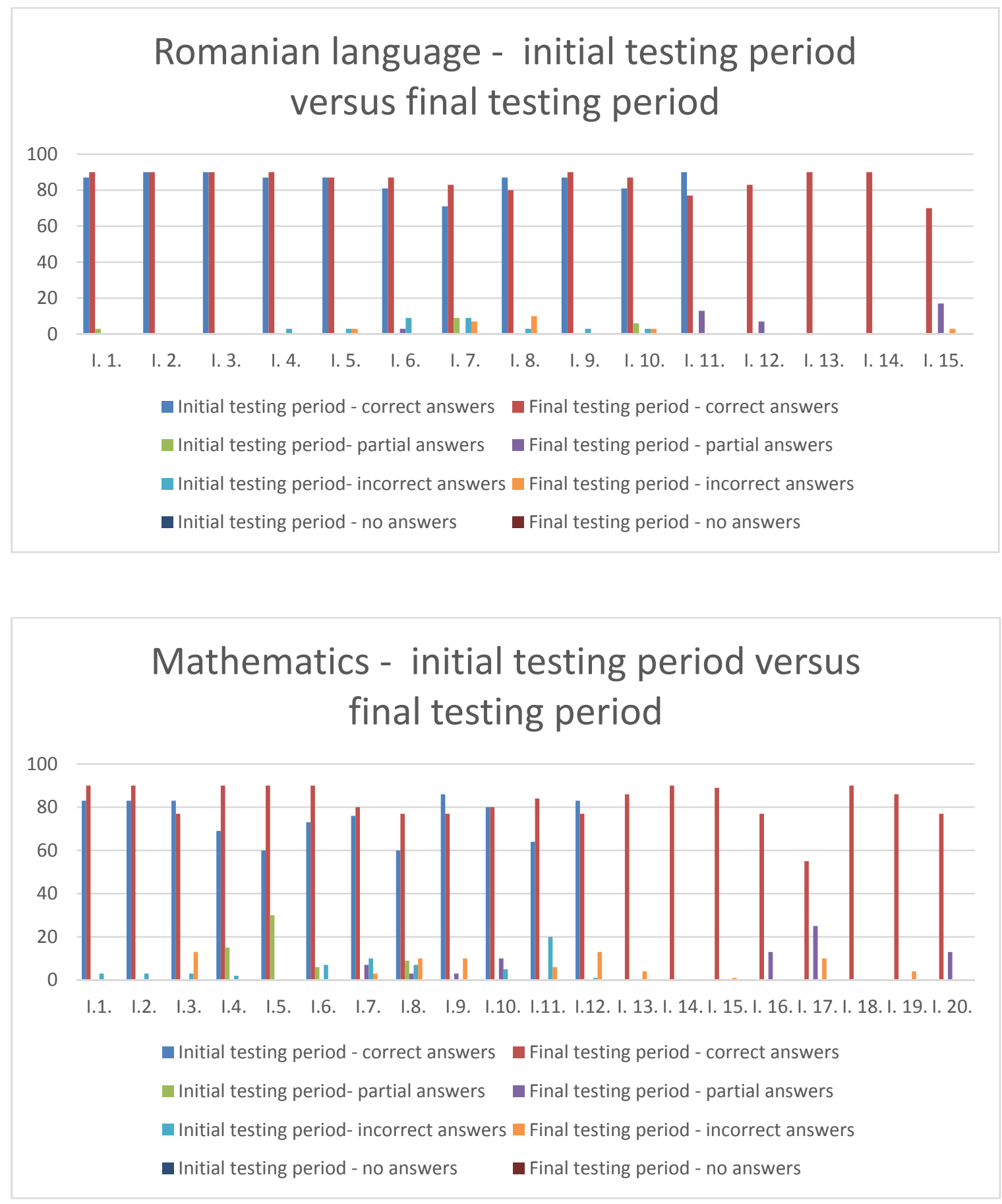


\section{Conclusion}

The systematic use of the interactive methods implies the development of the efficient and constructive communication relations, the acquisitions of the students being not only from the cognitive sphere, but also from the behavioural one, which thus contributes to the development of the personality.

The conduct of the experiment generated new horizons for future research, but it also shaped the limits of this action. Amongst these we enumerate the lack of pedagogical tradition in this domain in Romania, the initial training of the academic staff, predominantly focused on teaching each discipline in part, the latent opposition of the academic staff, the impossibility of thorough studying the scientific knowledge by students.

\section{References}

Albulescu, I., Albulescu, M. (1990). Didactica disciplinelor socioumane. Cluj-Napoca: Napoca Star, pg. 75, 66.

Armstrong, J. S. (2012). Natural Learning in Higher Education. Encyclopedia of the Sciences of Learning. Heidelberg: Springer.

Bocoș, M.-D. (2013). Instruirea interactivă. Repere axiologice și metodologice. laşi: Polirom, pg.138, 137, 293, 295, 308.

Cannon, R., D. Newbl, D. (2000). A Handbook for Teachers in University and Colleges, ed. a 4-a, Kogan Page, London, pg.16-17.

Gibbs, G. (1995). Assessing Student Centred Courses, Oxford: Oxford Centre for Staff Learning and Development.

Ionescu, M., Chiș, V. (1992). Strategii de predare și învățare. Bucureşti: Editura Științifică, pg. 85.
The responsible activation of students in the process of learning, the stimulation of collaborative work in groups of students who are assigned the same task, the decrease of the teacher's role as provider of information, the presentation of integrated contents consistent with students' intellectual and emotional needs, they are all sound arguments which come in support of student-centred learning and lead to long-lasting results. In this framework, the students have an active role in the quest for self-development, pursuing their educational needs, personal feelings and interests. This formative dimension is representative for the development of competences, understood as an operating mode which employs knowledge, skills and abilities, as well as for the development of attitudes towards knowledge and life.

Ionescu,M., Radu. I. (1995). Didactica modernă. Cluj-Napoca: Editura Dacia, pg. 162, 159.

Jones, L. (2007). The Student-Centered Classroom. Cambridge: University Press.

Johnson, E. (2013). The Student Centered Classroom: Vol 1: Social Studies and History, p. 19.

Latika, K. (2016). International Journal of Current Research and Modern Education (IJCRME), ISSN (Online): 2455-5428, Vol. 1(1), p. 677-680, June 2016.

Șoitu, L., Cherciu, R. D. (coord.) (2006). Strategii educaționale centrate pe elev. Buzău, Alpha MDN, pg. 60, 102, 154-156.

Student-Centered Learning. (2014). Education Reform Glossary. http://edglossary.org/student-centered-learning. 